\title{
Diet of invasive pikeperch Sander lucioperca: developing non-destructive tissue sampling for stable isotope analysis with comparisons to stomach contents analysis
}

\author{
Emma T. Nolan ${ }^{*}$ and J. Robert Britton \\ Department of Life and Environmental Sciences, Faculty of Science and Technology, Bournemouth University, BH12 5BB, UK
}

\begin{abstract}
Impact assessments of invasive piscivorous fishes usually rely on dietary analyses to quantify their predation pressure on prey communities. Stomach contents analysis (SCA), typically a destructive sampling method, is frequently used for this. However, many invasive piscivores are exploited by catch-andrelease sport angling, with destructive sampling often not feasible. Stable isotope analysis (SIA) provides an alternative dietary analysis tool to SCA, with use of fin tissue, scales and/or epidermal mucus potentially enabling its non-destructive application. Here, the diet of a population of pikeperch Sander lucioperca, an invasive sport fish to Great Britain, was investigated by applying SIA to a range of tissues. Testing SI data of dorsal muscle (destructive sampling) versus fin, scale and mucus (non-destructive sampling) revealed highly significant relationships, indicating that the tissues collected non-destructively can be reliably applied to pikeperch diet assessments. Application of these SI data to Bayesian mixing models predicted that as $S$. lucioperca length increased, their diet shifted from macro-invertebrates to fish. Although similar ontogenetic patterns were evident in SCA, this was inhibited by 54\% of fish having empty stomachs. Nevertheless, SCA revealed that as $S$. lucioperca length increased, their prey size significantly increased. However, the prey: predator length ratios ranged between 0.08 and 0.38 , indicating most prey were relatively small. These results suggest that when non-destructive sampling is required for dietary analyses of sport fishes, SIA can be applied using fin, scales and/ or mucus. However, where destructive sampling has been completed, SCA provides complementary dietary insights, especially in relation to prey size.
\end{abstract}

Keywords: Bayesian mixing models / gut contents / piscivory / trophic

\begin{abstract}
Résumé - Régime alimentaire du sandre Sander lucioperca : mise au point d'un échantillonnage non destructif des tissus pour l'analyse des isotopes stables et comparaisons avec l'analyse du contenu de l'estomac. Les évaluations de l'impact des poissons piscivores exotiques s'appuient généralement sur des analyses alimentaires pour quantifier la pression de prédation qu'ils exercent sur les communautés de proies. L'analyse du contenu stomacal (SCA), généralement une méthode d'échantillonnage destructive, est fréquemment utilisée à cette fin. Cependant, de nombreux piscivores exotiques sont exploités par la pêche sportive avec remise à l'eau, l'échantillonnage destructif étant souvent impossible. L'analyse des isotopes stables (SIA) est un outil d'analyse diététique alternatif à l'SCA, l'utilisation de tissus de nageoire, d'écailles et/ou de mucus épidermique permettant potentiellement son application non destructive. Ici, le régime alimentaire d'une population de sandre $S$. lucioperca, un poisson de pêche sportive envahissant, a été étudié en appliquant le SIA à une gamme de tissus. L'analyse des données du SI du muscle dorsal (échantillonnage destructif) par rapport aux nageoires, à l'écaille et au mucus (échantillonnage non destructif) a révélé des relations très significatives, indiquant que les tissus recueillis de façon non destructive peuvent être appliqués de façon fiable aux évaluations du régime alimentaire du sandre. L'application de ces données du SI aux modèles de mélange bayésiens a estimé qu'à mesure que la longueur de S. lucioperca augmentait, leur alimentation passait des macro-invertébrés aux poissons. Bien que des schémas ontogénétiques similaires aient été observés chez les SCA, ils ont été limités par 54\% des poissons ayant l'estomac vide. Néanmoins, SCA a révélé qu'à mesure que la longueur de $S$. lucioperca augmentait, la taille de leurs proies augmentait considérablement. Cependant, le rapport proie : longueur des prédateurs variait entre 0,08 et 0,38, ce qui
\end{abstract}


indique que la plupart des proies étaient relativement petites. Ces résultats suggèrent que lorsqu'un échantillonnage non destructif est nécessaire pour l'analyse du régime alimentaire de poissons de pêche sportive exotiques, le SIA peut être appliquée en utilisant des nageoires, des écailles et/ou du mucus. Cependant, lorsque l'échantillonnage destructif a été effectué, l'ACS fournit des informations complémentaires sur l'alimentation, en particulier en ce qui concerne la taille des proies.

Mots-clés : modèles bayésiens de mélange / carbone / contenu intestinal / azote / piscivorie / écologie trophique

\section{Introduction}

Piscivorous fishes play an important role in regulating the structure of aquatic food-webs (Woodward and Hildrew, 2002). They can exert substantial top-down forces on prey communities, potentially initiating trophic cascades (Brett and Goldman, 1996; Pace et al., 1999; Drenner and Hambright, 2002). Alien piscivorous fishes that are introduced to enhance sport angling, such as largemouth bass Micropterus salmoides and peacock bass Cichla spp., also exert substantial top-down forces on prey fish communities, resulting in impacts including reduced prey abundances and decreased species diversity (Gratwicke and Marshall 2001; Pelicice and Agostinho, 2009). As the diets of piscivorous fishes tend to involve strong ontogenetic changes via increasing gape sizes (Zhao et al., 2014), the strength of trophic cascades can be strongly influenced by the resultant dietary shifts (Sato and Watanabe, 2014). Thus, an important step in the assessments of the ecological impacts of invasive piscivores is analyses of their diet composition, including assessing ontogenetic shifts in their prey selection.

Dietary assessments of piscivorous fishes are often reliant on stomach contents analysis (SCA) (Sandlund et al., 2016). Whilst providing information on diet composition of individual fish, the method usually utilises relatively large numbers of fish to maximise statistical power and to assist understandings of dietary patterns over time and space (Cortés, 1997). For piscivores such as Northern pike (Esox lucius) and pikeperch ( $S$. lucioperca), an inherent issue in stomach contents analysis is that many of the fish often have empty stomachs, resulting in a paucity of dietary data from the sampled population. Piscivorous fishes in general and particularly those that consume prey whole have higher proportions of empty stomachs compared to lower trophic level fishes (Arrington et al., 2002), with feeding frequency thought to decrease through the consumption of energy-rich food items (Bowen et al., 1995). These methodological issues can potentially be overcome by using complementary dietary assessment methods, such as stable isotope analysis (SIA) (Cucherousset et al., 2012; Jensen et al., 2012). Indeed, in a study where an average of $36 \%$ of E. lucius had empty stomachs across 16 populations, stable isotope analysis showed no trophic position differences between fish with and without prey items in their stomachs, or between piscivorous and invertebrate feeders determined through stomach content analysis (Paradis et al., 2008), indicating opportunistic rather than specialist invertebrate feeding strategies. Therefore, integrative studies may often show that SCA and SIA provide contrasting dietary information due to, for example, differences in the temporal scales of the methods (i.e. short-term SCA versus long-term SIA diet assessments),
(Locke et al., 2013; Busst and Britton, 2017), but these differences can provide insights where disintegrated studies cannot.

The issues of sacrificing relatively large numbers of piscivorous fish to satisfy the requirements needed for stomach contents analysis is also problematic when these fish have high values within sport angling. For example, catch and release angling $(\mathrm{C} \& \mathrm{R})$ is increasingly applied to sport fishing for species such as M. salmoides, S. lucioperca and Cichla spp. Mortalities associated with C\&R can be minimised via use of best practice angling techniques and fish handling codes (Siepker et al., 2007; Arlinghaus and Hallermann, 2007; Cook et al., 2015, Bower et al., 2016). Consequently, dietary assessments for piscivorous sport fishes based on destructive sampling are increasingly at odds with their fishery management and angling practises, even where the fishes are invasive (Hickley and Chare, 2004). Indeed, the fishery value of invasive fishes are increasingly recognised (Gozlan, 2008), especially when their populations are in large open systems in which their population management is inherently difficult (Britton et al., 2011; Britton and Orsi, 2012).

Pikeperch $S$. lucioperca is a large-bodied piscivorous freshwater fish whose native range in Europe extends from Germany in the West to Central Russia in the East (Maitland, 2004). The species has been introduced outside of this range, into countries such as France, Spain and Great Britain (Elvira and Almodóvar, 2001; Kopp et al., 2009), often with the primary purpose of increasing sport angling opportunities (Hickley and Chare, 2004). Following their initial introduction into Britain in 1878 , there was a series of translocations of S. lucioperca into waters in Eastern England during the 1960s (Wheeler and Maitland, 1973). It was these releases that resulted in their invasion of river catchments across Eastern, Central and Southern England (Linfield and Rickards, 1979; Hickley, 1986; Copp et al., 2003). Whilst there were initial concerns on their impacts on prey populations, the species is now considered as an important angler target species in many fisheries (Hickley and Chare, 2004). Consequently, whilst studies on their diet previously utilised stomach contents analyses (e.g. Smith et al., 1997; Schulze et al., 2006), methods based on stable isotope analysis might now be more preferable (Kopp et al., 2009), especially where tissues can be utilised that can be collected non-lethally (Britton and Busst, 2018).

The diet of the $S$. lucioperca has been well studied both within their native and non-native ranges (e.g. Campbell 1992; Keskinen and Marjomäki 2004; Pérez-Bote and Roso 2012; Didenko and Gurbyk 2016). They are generally considered to be piscivorous within their first year of life (Mittelbach and Persson 1998), although this switch to piscivory can become delayed if individuals do not reach a size advantage over prey (Persson and Brönmark 2002) or if suitable prey fish are 
unavailable (Ginter et al., 2011). While S. lucioperca diet comprises of fish across a range of size classes, they can also be cannibalistic, with this acting as an important regulatory force (Mehner et al., 1996; Frankiewicz et al., 1999; Lappalainen et al., 2006). Individual S. lucioperca will also consume macro-invertebrates, with these prey items most frequently encountered in the diets of smaller individuals (Hansson et al., 1997; Argillier et al., 2012).

The application of SIA using multiple tissues in conjunction with SCA enables the dietary habits of the target population to be assessed across difference timescales. SCA provides 'snapshot' dietary information (Cortés, 1997). By contrast, SIA provides longer term dietary perspectives, with the timescale dependent on the analysed tissue (Fry, 2006; Newsome et al., 2007; Martínez del Rio et al., 2009). The aim of this study was thus to use $S$. lucioperca as a model fish exploited by $\mathrm{C} \& \mathrm{R}$ sport angling to assess how stable isotope analysis can be applied to assess their diet in relation to using tissues that are collected non-destructively. Objectives were to (1) quantify the relationships of the stable isotopes of $\delta^{13} \mathrm{C}$ and $\delta^{15} \mathrm{~N}$ between dorsal muscle and three tissues that can be collected non-lethally; (2) utilise the stable isotope data to predict the diet composition of a $S$. lucioperca population using Bayesian mixing models (Stock et al., 2018); and (3) complete stomach contents analyses on the $S$. lucioperca population and assess the results in the context of the dietary predictions from the mixing models.

\section{Materials and methods}

\subsection{Sample collection}

The S. lucioperca population of the Grand Union Canal, Northamptonshire, in Central England was sampled by boatmounted electric fishing ('boom-boat', power supplied by a $2 \mathrm{kVA}$ generator) in April 2017. This canal is generally of $15 \mathrm{~m}$ maximum width and depth rarely exceeds $2 \mathrm{~m}$. A series of locks overcome changes in the gradient of the surrounding land. Small-bodied cyprinid fishes are dominant in the fish community, especially roach Rutilus rutilus. Pikeperch have been present in the canal for at least 30 years (Hickley, 1986). A total of 180 individuals were captured by electric fishing that ranged in fork length (to nearest $\mathrm{mm}$ ) between 169 and $551 \mathrm{~mm}$ (mean $\pm 95 \% \mathrm{CI} ; 355 \pm 14 \mathrm{~mm}$ ) and weight between 48 and $1924 \mathrm{~g}($ mean $\pm 95 \% \mathrm{CI} ; 561 \pm 71 \mathrm{~g})$. Following their capture, the fish were euthanised and held on ice while being transferred to the laboratory where they were processed immediately.

\subsection{Stable isotope analysis}

Of the 180 sampled $S$. lucioperca, a sub-sample of 19 were processed for stable isotope analysis using fish from across the length range (mean $\pm 95 \% \mathrm{CI} ; 323 \pm 54 \mathrm{~mm}$ ). Following their measurement, the tissues that were sampled from each fish were dorsal muscle, pelvic fin tissue, scales and epidermal mucus. The epidermal mucus was collected by scraping the dorsal surface of each fish with a cover slip, with the sample then cleaned with forceps as per Maruyama et al. (2015) and transferred to a sample tube. This method was used in preference to the filtration method of Church et al. (2009), as it was demonstrated to result in reduced error (Maruyama et al., 2017). Scales were collected from the body area between the dorsal fin and the lateral line. Scale decalcification was not performed prior to isotopic analysis, since the removal of inorganic carbonates has been shown to have no significant effect on scale $\delta^{13} \mathrm{C}$ and $\delta^{15} \mathrm{~N}$ values (Sinnatamby et al., 2007; Ventura and Jeppesen, 2010; Woodcock and Walther, 2014). Preparation thus focused on cleaning scales with distilled water prior to removing the outer portion of the scale for SIA, ensuring the tissue analysed was from recent growth only ( 1 year) (Hutchinson and Trueman, 2006; Bašić and Britton, 2015). A selection of all prey fish species (dorsal muscle only) and macroinvertebrates ( $c f$. Stomach content analysis) were also prepared for stable isotope analysis recovered through dissection and removal of prey from the stomachs. These samples were based only on individual animals that were recovered in good condition, i.e. those very recently ingested, with negligible digestion and that were identifiable to species level. All samples were then dried at $60^{\circ} \mathrm{C}$ for $48 \mathrm{~h}$.

The samples were then analysed at the Cornell Isotope Laboratory, New York, USA, where they were ground to powder, weighed precisely to approximately $1000 \mu \mathrm{g}$ and analysed on a Thermo Delta $\mathrm{V}$ isotope ratio mass spectrometer (Thermo Scientific, USA) interfaced to a NC2500 elemental analyser (CE Elantach Inc., USA). Verification of accuracy was against internationally known reference material and accuracy and precision of the sample runs was tested every 10 samples using a standard animal sample (mink). Delta $(\delta)$ isotope ratios were expressed as units per mil (\%o). Analytical precision of the $\delta^{15} \mathrm{~N}$ and $\delta^{13} \mathrm{C}$ sample runs was estimated at 0.42 and $0.15 \%$ respectively. Lipid correction was not necessary as $\mathrm{C}: \mathrm{N}$ ratios indicated very low lipid content (Post et al., 2007).

\subsection{Tissue comparisons}

The significance of differences in the stable isotope ratios between the tissues were tested using pair-wise $t$-tests. Simple linear regression models tested the significance of the relationship between mucus and muscle, fin and muscle and scale and muscle for $\delta^{13} \mathrm{C}$ and $\delta^{15} \mathrm{~N}$ isotope values. Models were run both with and without fish length. The best fitting model was chosen using regression statistics and the lowest value of Akaike's Information Criteria (AIC). Statistical analysis and graphical outputs were performed using $\mathrm{R}$ (R Core Team, 2018, version 3.4.3).

\subsection{Bayesian mixing models}

The stable isotope data were analysed to assess the effect of tissue type on fish diet predictions, including after conversion of the stable isotope data of the non-lethal tissues to dorsal muscle (as the standard tissue used in fish isotope studies). The primary tool for these analyses was the use of Bayesian mixing models (Phillips et al., 2014) allowing for predictions of the relative proportions of the putative prey resources that contributed to the diet of $S$. lucioperca for each tissue both before and after their conversion to dorsal muscle values. The models were run in the package 'Mixing Models for Stable Isotope Analysis in R' (MixSIAR; Parnell et al., 2013; 
Table 1. Number of individuals, tissue specific carbon $\left(\delta^{13} \mathrm{C}\right)$ and nitrogen $\left(\delta^{15} \mathrm{~N}\right)$ stable-isotope ratios $(\mathrm{Mean} \pm \mathrm{SD})$ indicating variation in isotope values between tissues.

\begin{tabular}{llllll}
\hline Tissue & $n$ & $\delta^{13} \mathrm{C} \%$ o & Range & $\delta^{15}$ N\%o & Range \\
\hline Muscle & 19 & $-31.68 \pm 0.77$ & -32.90 to -30.36 & $21.26 \pm 1.03$ & 19.15 to 22.94 \\
Mucus & 19 & $-32.23 \pm 1.04$ & -34.15 to -30.84 & $20.88 \pm 1.03$ & 18.95 to 22.39 \\
Fin & 19 & $-31.15 \pm 1.13$ & -33.38 to -29.13 & $21.27 \pm 1.10$ & 19.15 to 22.84 \\
Scale & 19 & $-28.67 \pm 0.70$ & -29.68 to -27.37 & $19.99 \pm 1.11$ & 17.61 to 21.80 \\
\hline
\end{tabular}

Stock et al., 2018). All models were run using normal run length (chain length: 100,000 iterations with burn-in of 50,000, with posterior thinning (thin: 50) and 3 chains). Model diagnostics were based on Gelman-Rubin and Geweke, with sufficient convergence to accept the results (Stock and Semmens, 2016).

Five mixing models were run that covered the use of the S. lucioperca (as the consumer) stable isotope data from (1) dorsal muscle, (2) epidermal mucus, (3) scales, (4) epidermal mucus data converted to dorsal muscle values (using the linear models for $\delta^{13} \mathrm{C}$ and $\delta^{15} \mathrm{~N}$ mucus to muscle), and (5) scale data converted to dorsal muscle values (using the linear models for $\delta^{13} \mathrm{C}$ and $\delta^{15} \mathrm{~N}$ scale to muscle). The putative prey (source) data used within the mixing models was constant across all models, except for model (3) where fish muscle isotope data were converted to scale data based on conversion factors in Busst et al. (2015) to ensure consistency in predictions by accounting for differences in isotope values between the tissues of source and consumer. Dietary contributions were predicted by splitting the fish into two size classes, $<350$ and $>350 \mathrm{~mm}$, with distinctions made between the two groupings based on (1) the likelihood of sexual maturity at above approximately $350 \mathrm{~mm}$ (Lappalainen et al., 2003) and (2) differences in the contribution of prey items to the diet of individuals in each size class from stomach content analysis ( $c f$. results).

In the mixing models, the isotopic fractionation values between the prey resources and S. lucioperca were varied according to the $S$. lucioperca tissue being used. For muscle and mucus, values were chosen based on standards proposed by Post (2002): $\delta^{15} \mathrm{~N} 3.4 \pm 0.5 \%$; $\delta^{13} \mathrm{C} 1 \pm 0.5 \%$. For scales, the fractionation factors used were $\delta^{15} \mathrm{~N}=2.58 \pm 1 \%$ and $\delta^{13} \mathrm{C}=2.78 \pm 1 \%$ ), based on the standards of Post (2002) but with correction for scales using the mean differences from three studies comparing fractionation between muscle and scale tissue $\left(\Delta^{15} \mathrm{~N}-0.82 \%, \Delta^{13} \mathrm{C} 1.78 \%\right.$ ) (Heady and Moore, 2013; Busst and Britton, 2015; Busst et al., 2015).

Reported outputs of the models were overall estimated posterior density contributions to diet given as summary statistics; mean, standard deviation and 95\% confidence limits. Posterior density plots for each model are given in supplementary material.

\subsection{Stomach content analysis}

S. lucioperca were measured (fork length, nearest $\mathrm{mm}$ ) and weighed (nearestg), and then dissected and their stomach contents removed. Prey items from stomach contents were identified to their lowest possible taxonomic level, total stomach fullness (\% in volume) was assessed, as was the contribution of each prey item to overall fullness. For subsequent analyses, stomach contents were categorised into three groupings consisting of (1) 'Cyprinidae' including roach Rutilis rutils, common bream Abramis brama and gudgeon Gobio gobio; (2) 'Percidae' including perch Perca fluviatilis and ruffe Gymnocephalus cernua; and (3) 'Invertebrates' where macro-invertebrates were identified to family level, and included Gammaridae, Chironomidae and Mysidae.

The contribution of each diet category was expressed as percentages in terms of frequency of occurrence and preyspecific abundance. Frequency of occurrence $\left(\% F_{i}\right)$ of a given prey type was defined as the number of stomachs in which that prey occurred, expressed as a frequency of the total number of stomachs in which prey were present (Costello, 1990). For prey-specific abundance, prey-type contribution was first estimated in proportion to overall stomach fullness (in volume). The proportional fullness contribution of each diet category was then expressed as percentage prey-specific abundance $\left(\% P_{i}\right)$ :

$$
\% P_{i}=\left(\frac{\sum F_{i}}{\sum F_{t}}\right) \times 100,
$$

where $P_{i}$ was the prey-specific abundance of prey $i, F_{i}$ was the stomach content fullness for diet category $i$ and $F_{t}$ was the total stomach fullness in only those predators with prey $i$ in their stomach (Amundsen et al., 1996). In addition, the fork length $(\mathrm{mm})$ of each prey item was also taken to assess changes in prey use patterns with increasing body length of $S$. lucioperca using regression analysis (as prey: predator length ratios). Dietary contribution was predicted for size classes $<350$ and $>350 \mathrm{~mm}$ as per Bayesian mixing models.

\section{Results}

\subsection{Relationship of $\delta^{13} \mathrm{C}$ and $\delta^{15} \mathrm{~N}$ values between S. lucioperca tissues}

There was a significant difference in the $\delta^{13} \mathrm{C}$ values between scale and all other tissues (Tab. 1, Fig. 1), where scale was significantly enriched in $\delta^{13} \mathrm{C}$ relative to muscle $(t$-test, $t=12.6, P<0.001)$, mucus ( $t$-test, $t=12.4, P<0.001)$ and fin ( $t$-test, $t=8.1, P<0.001)$. Although not significantly different, mucus was depleted in $\delta^{13} \mathrm{C}$ relative to muscle $(-0.55 \%$; $t$-test, $t=-1.8, P=0.07)$, whilst fin was enriched in $\delta{ }^{13} \mathrm{C}$ relative to muscle $(+0.53 \%$; $t$-test, $t=1.6, P=0.10)$. For $\delta{ }^{15} \mathrm{~N}$, significant differences were also evident between scale and all other tissues (Tab. 1, Fig. 1), with scale depleted in $\delta^{15} \mathrm{~N}$ relative to muscle $(-1.25 \% ; t$-test, $t=-3.6, P<0.001)$, mucus ( $t$-test, $t=-2.5, P<0.001)$ and fin $(t$-test, $t=-3.5$, 


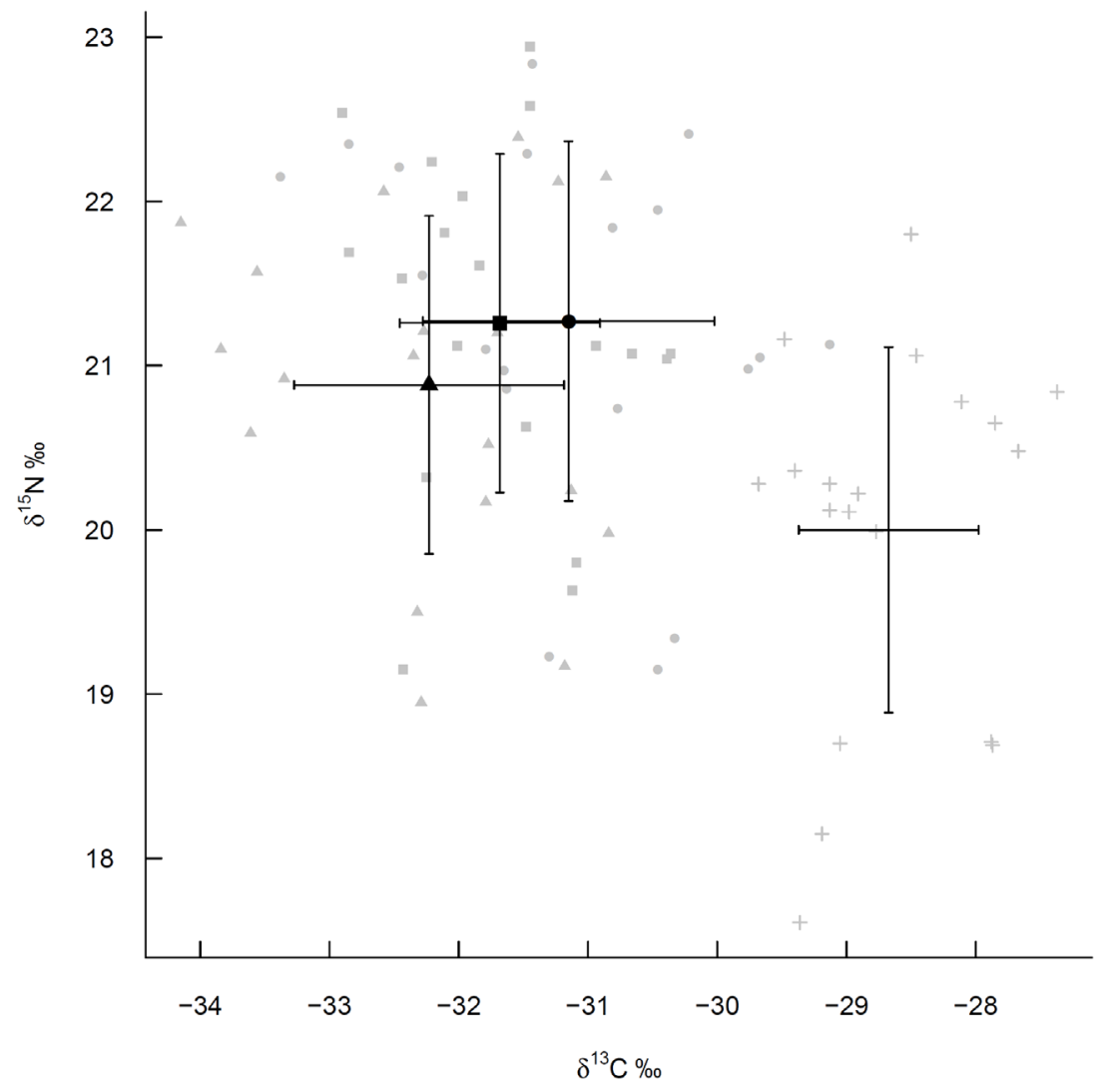

Fig. 1. Stable isotope bi-plot of $\delta^{13} \mathrm{C}$ versus $\delta^{15} \mathrm{~N}$ showing individual (light grey) and mean (black) values for all tissue types ( $\square$ muscle; $\Delta$ mucus; fin; + scale), where error bars represent standard deviation.

Table 2. Linear regression statistics for the relationship between dorsal muscle stable isotope values $\left(\delta^{13} \mathrm{C}\right.$ and $\left.\delta^{15} \mathrm{~N}\right)$ and those of epidermal mucus, fin and scales collected from $S$. lucioperca.

\begin{tabular}{lllllllll}
\hline Isotope & Relationship & $R^{2}$ & $F$ & & $P$ & $a$ & $b_{1}(95 \%$ CI $)$ & $b_{2}(95 \%$ CI $)$ \\
\hline$\delta^{13} \mathrm{C}$ & Muscle/Mucus & 0.63 & (DF 1,17) 32.18 & $<0.001$ & -12.34 & $0.60(0.37,0.82)$ & \\
& Muscle/Mucus + length & 0.75 & (DF 2,16) 28.32 & $<0.001$ & -22.64 & $0.31(0.04,0.58)$ & $0.003(0.001,0.006)$ & 22.45 \\
& Muscle/Fin & 0.80 & (DF 1,17) 74.45 & $<0.001$ & -12.37 & $0.62(0.47,0.77)$ & \\
& Muscle/Fin + length & 0.82 & (DF 2,16) 42.34 & $<0.001$ & -18.04 & $0.46(0.20,0.71)$ & $0.001(-0.001,0.004)$ & 16.23 \\
& Muscle/Scale & 0.86 & (DF 1,17) 111.9 & $<0.001$ & -1.90 & $1.04(0.83,1.25)$ & & \\
& Muscle/ Scale + length & 0.86 & (DF 2,16) 56.4 & $<0.001$ & -6.69 & $0.88(0.49,1.27)$ & $0.001(-0.001,0.003)$ & 11.57 \\
$\delta^{15} \mathrm{~N}$ & Muscle/Mucus & 0.28 & (DF 1,17) 8.152 & 0.01 & 9.35 & $0.57(0.15,0.99)$ & & 52.60 \\
& Muscle/Mucus + length & 0.51 & (DF 2,16) 10.32 & 0.001 & 8.14 & $0.70(0.33,1.05)$ & $-0.004(-0.007,-0.001)$ & 46.29 \\
& Muscle/Fin & 0.75 & (DF 1,17) 56.5 & $<0.001$ & 3.71 & $0.83(0.59,1.06)$ & & 32.22 \\
& Muscle/Fin + length & 0.75 & (DF 2,16) 28.18 & $<0.001$ & 4.57 & $0.79(0.55,1.04)$ & $-0.001(-0.003,0.001)$ & 33.36 \\
& Muscle/Scale & 0.69 & (DF 1,17) 41.42 & $<0.001$ & 5.65 & $0.78(0.52,1.04)$ & & 36.58 \\
& Muscle/Scale + length & 0.88 & (DF 2,16) 72.21 & $<0.001$ & 5.88 & $0.82(0.67,0.99)$ & $-0.004(-0.005,-0.002)$ & 18.24 \\
\hline
\end{tabular}

$P<0.001)$. There was no significant difference in $\delta^{15} \mathrm{~N}$ between muscle and mucus $(+0.38, t$-test, $t=1.1, P=0.27)$ or between muscle and fin $(-0.01 ; t$-test, $t=-0.1, P=0.97)$.

Significant relationships were found between $S$. lucioperca muscle isotope values $\left(\delta^{13} \mathrm{C}\right.$ and $\left.\delta^{15} \mathrm{~N}\right)$ and all other tissue types (Tab. 2, Fig. 2). Including length in the models improved their fit in all cases (according to AIC and regression statistics; Tab. 2). This is likely explained by the significant increase in $\delta^{13} \mathrm{C}$ with increasing fish length (Fig. 3; muscle, $R^{2}=0.68 ; F_{(1,17)}=39.2 ; P<0.001 ;$ mucus, $R^{2}=0.52$; $F_{(1,17)}=20.1 ; \quad P<0.001 ;$ fin, $R^{2}=0.66 ; \quad F_{(1,17)}=35.4$; $P<0.001 ;$ scale, $\left.R^{2}=0.70 ; F_{(1,17)}=42.91 ; P<0.001\right)$. Consequently, length was retained in the regression analyses across all tissue/isotope conversions for consistency. There was no relationship between $\delta^{15} \mathrm{~N}$ and fish length (muscle, $R^{2}=0.06 ; F_{(1,17)}=2.12 ; P=0.16$; mucus, $R^{2}=0.01$; $F_{(1,17)}=1.12 ; P=0.31$; fin, $R^{2}=0.02 ; F_{(1,17)}=1.32 ; P=0.27$; scale, $\left.R^{2}=0.01 ; F_{(1,17)}=0.25 ; P=0.62\right)$. 

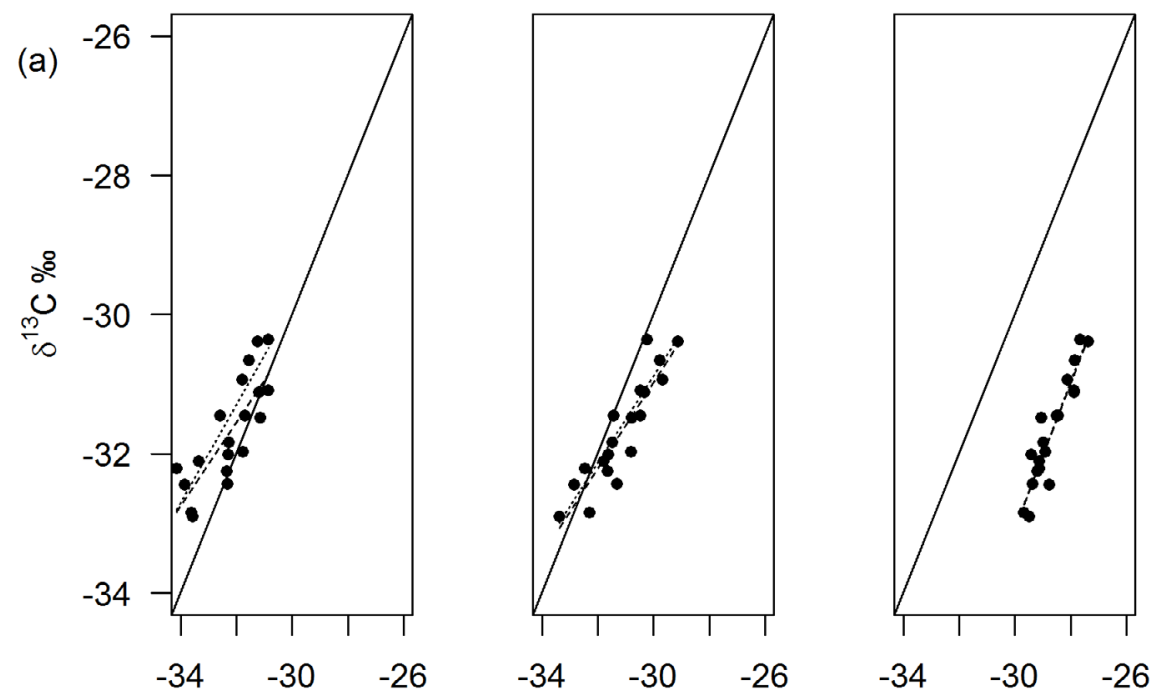

(b)
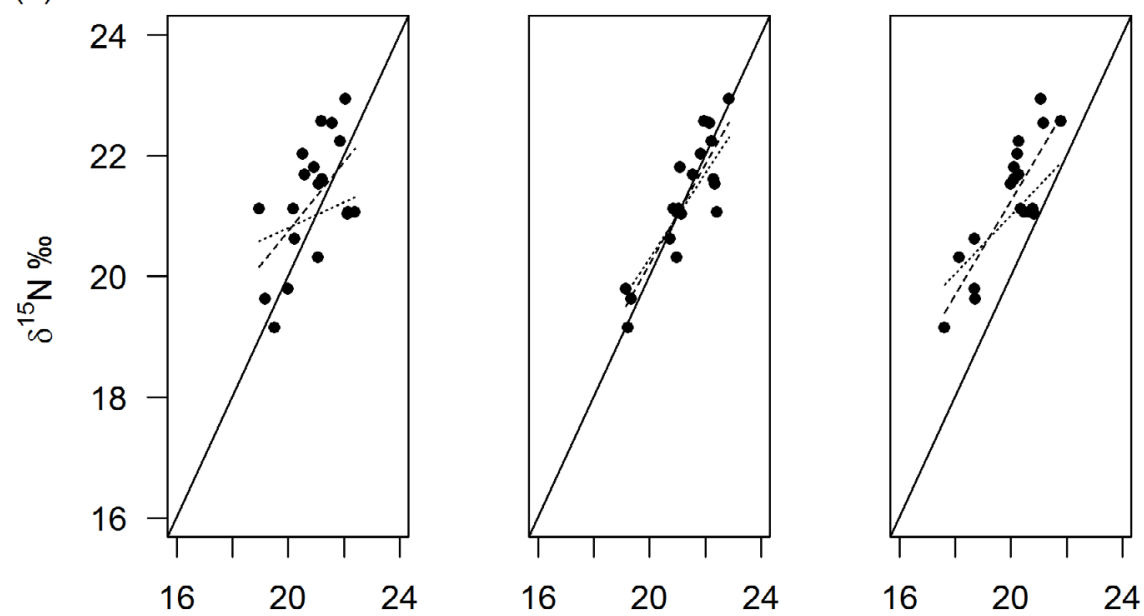

Mucus

Fin

Scale

Fig. 2. Linear relationships of (a) $\delta^{13} \mathrm{C}$ and (b) $\delta^{15} \mathrm{~N}$ dorsal muscle versus epidermal mucus ('mucus'), fin and scale, where the dotted line represents the relationship with length included in the model and the dashed line represents the relationship with length excluded.

\subsection{Stable isotope mixing models}

The mixing models predicted the diet category 'invertebrates' to be the most important item to the diet of $S$. lucioperca $<350 \mathrm{~mm}$, followed by Cyprinidae and then Percidae (Tab. 3). This result was consistent across all models (Tab. 3, Fig. 4). For $S$. lucioperca $>350 \mathrm{~mm}$, Cyprinidae had the greatest predicted contribution to $S$. lucioperca diet, followed by invertebrates and then Percidae (Tab. 3, Fig. 4).

The difference in mean dietary contribution predictions across size classes between model 1 (muscle) and all other models was lowest for model 5 (scale data converted to dorsal muscle values) (Tab. 3, Fig. 4). Differences were greatest between model 1 (muscle) and model 2 (mucus) for mean dietary contribution predictions in size class $<350 \mathrm{~mm}$ and for Percidae in size class $>350 \mathrm{~mm}$, whereas differences were greatest between model 1 (muscle) and model 4 (epidermal mucus data converted to dorsal muscle values) for Cyprinidae and Invertebrates in size class $>350 \mathrm{~mm}$ (Tab. 3, Fig. 4).

\subsection{Stomach contents analysis}

Of the 180 sampled $S$. lucioperca, 98 had empty stomachs $(54 \%)$. Of the 82 fish with items in the stomach, analyses revealed that as $S$. lucioperca body size increased, the size of their prey significantly increased (Cyprinidae: $R^{2}=0.41$, $F_{(1,65)}=46.48, P<0.01$; Percidae: $R^{2}=0.43, F_{(1,6)}=6.28$, $P=0.05$ ) (Fig. 5a). Between the two fish prey groups, there was no significant difference in their sizes (ANOVA $\left.F_{1,72}=0.35, P=0.56\right)$. Regarding prey: predator length ratios, these ratios generally decreased as $S$. lucioperca body size increased, although the relationships were not significant (Cyprinidae: $R^{2}=0.03, \quad F_{(1,65)}=2.23, \quad P=0.14 ; \quad$ Percidae: 

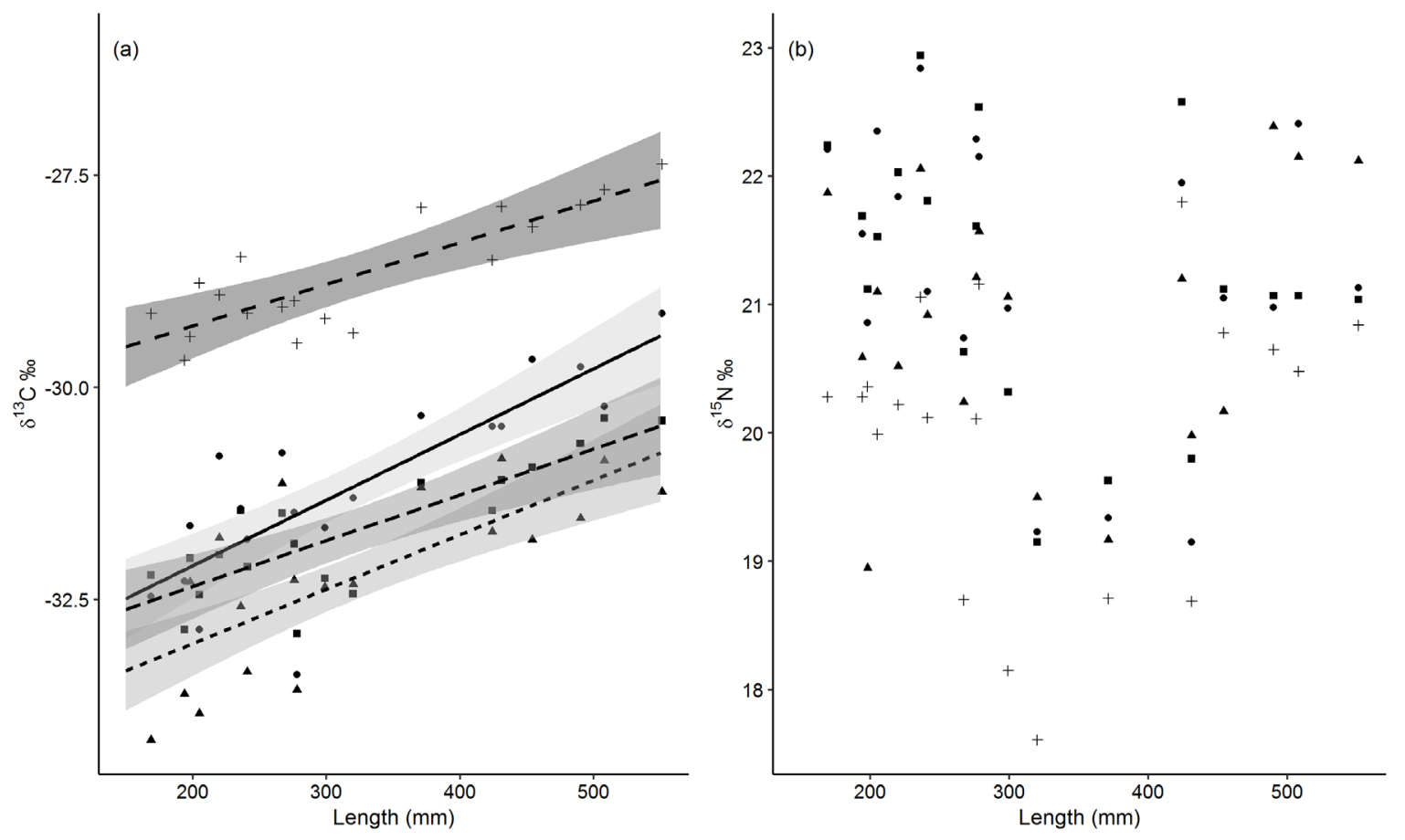

Fig. 3. Linear relationships of (a) $\delta^{13} \mathrm{C}$ and (b) $\delta^{15} \mathrm{~N}$ for muscle $(\boldsymbol{\square})$, mucus $(\boldsymbol{A})$, fin $(\boldsymbol{O})$ and scale $(+)$. Significant relationships are fitted with $95 \%$ confidence intervals around the line for muscle (long dashed line, light grey), mucus (short dashed line), fin (solid line) and scale (long dashed line, dark grey).

Table 3. Mean predicted dietary contributions from Bayesian mixing models of 'Cyprinidae', 'Invertebrates' and 'Percidae' to the diet of S. lucioperca by size class $(<350 \mathrm{~mm}$ and $>350 \mathrm{~mm})$, showing standard deviation and $95 \%$ confidence limits. Mixing models were (1) consumer as muscle values, (2) consumer as mucus values, (3) consumer as scale values, (4) consumer as muscle values based on conversion using the linear models for $\delta^{13} \mathrm{C}$ and $\delta^{15} \mathrm{~N}$ mucus to muscle, and (5) consumer as muscle values based on conversion using the linear models for $\delta^{13} \mathrm{C}$ and $\delta^{15} \mathrm{~N}$ scale to muscle.

\begin{tabular}{|c|c|c|c|c|c|c|c|c|c|}
\hline \multirow[t]{2}{*}{ Resource } & \multirow[t]{2}{*}{ Model } & \multicolumn{4}{|c|}{$\mathrm{I}<350 \mathrm{~mm}$} & \multicolumn{4}{|c|}{$\mathrm{II}>350 \mathrm{~mm}$} \\
\hline & & Mean & SD & $2.5 \% \mathrm{CI}$ & $95.7 \% \mathrm{CI}$ & Mean & SD & $2.5 \% \mathrm{CI}$ & $95.7 \% \mathrm{CI}$ \\
\hline \multirow[t]{5}{*}{ Cyprinidae } & 1 & 0.32 & 0.13 & 0.07 & 0.552 & 0.47 & 0.22 & 0.04 & 0.83 \\
\hline & 2 & 0.23 & 0.11 & 0.03 & 0.459 & 0.45 & 0.21 & 0.02 & 0.79 \\
\hline & 3 & 0.28 & 0.11 & 0.07 & 0.499 & 0.40 & 0.18 & 0.05 & 0.73 \\
\hline & 4 & 0.27 & 0.11 & 0.07 & 0.498 & 0.40 & 0.20 & 0.04 & 0.76 \\
\hline & 5 & 0.31 & 0.12 & 0.07 & 0.535 & 0.46 & 0.21 & 0.04 & 0.81 \\
\hline \multirow[t]{5}{*}{ Invertebrates } & 1 & 0.46 & 0.1 & 0.26 & 0.646 & 0.27 & 0.14 & 0.06 & 0.60 \\
\hline & 2 & 0.63 & 0.11 & 0.4 & 0.811 & 0.33 & 0.13 & 0.11 & 0.59 \\
\hline & 3 & 0.50 & 0.09 & 0.33 & 0.668 & 0.31 & 0.09 & 0.13 & 0.50 \\
\hline & 4 & 0.49 & 0.09 & 0.31 & 0.648 & 0.38 & 0.17 & 0.10 & 0.76 \\
\hline & 5 & 0.47 & 0.09 & 0.27 & 0.65 & 0.28 & 0.13 & 0.06 & 0.58 \\
\hline \multirow[t]{5}{*}{ Percidae } & 1 & 0.23 & 0.12 & 0.03 & 0.475 & 0.26 & 0.19 & 0.01 & 0.68 \\
\hline & 2 & 0.15 & 0.10 & 0.01 & 0.375 & 0.22 & 0.18 & 0.004 & 0.64 \\
\hline & 3 & 0.22 & 0.10 & 0.04 & 0.439 & 0.29 & 0.16 & 0.02 & 0.62 \\
\hline & 4 & 0.24 & 0.1 & 0.05 & 0.443 & 0.23 & 0.16 & 0.02 & 0.59 \\
\hline & 5 & 0.23 & 0.11 & 0.04 & 0.454 & 0.27 & 0.18 & 0.02 & 0.68 \\
\hline
\end{tabular}

$R^{2}=0.09, F_{(1,6)}=0.58, P=0.47$ ) (Fig. 5b). The maximum prey length to predator length ratio was 0.38 , whilst the minimum was 0.08 (mean $\pm \mathrm{SD} ; 0.22 \pm 0.06$ ), with the majority of $S$. lucioperca consuming small prey sizes relative to their body size $(85 \%$ of prey $<0.3$ prey length/predator length; Fig. $5 \mathrm{c})$.
The prey-specific abundance $\left(\% P_{i}\right)$ was highest for Cyprinidae at $79.8 \%$, followed by Percidae $(13.1 \%)$ and then invertebrates $(7.11 \%)$ (Tab. 4). Invertebrates were only represented in the diet of individuals up to $396 \mathrm{~mm}$, whilst Cyprinidae were present in individuals from 204 to $532 \mathrm{~mm}$ 

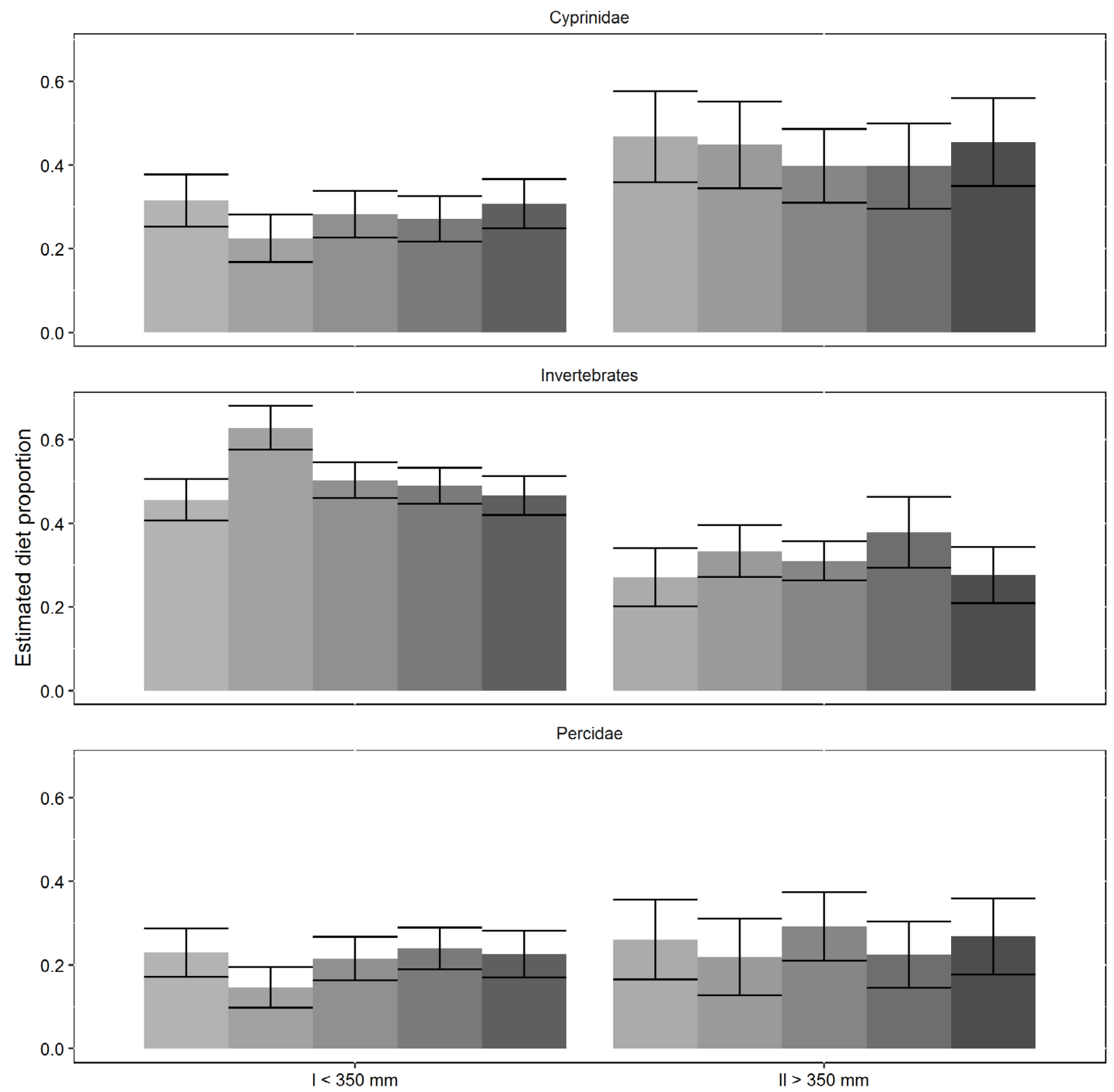

Fig. 4. Mean predicted dietary contributions (0-1) of 'Cyprinidae', 'Invertebrates' and 'Percidae' to the diet of $S$. lucioperca by size class $(<350$ and $>350 \mathrm{~mm})$ for each Bayesian mixing model. Models are represented by colour in sequence from light to dark, where model 1 is represented by light grey and model 5 by dark grey, and error bars represent the standard deviation. Mixing models were (1) consumer as muscle values, (2) consumer as mucus values, (3) consumer as scale values, (4) consumer as muscle values based on conversion using the linear models for $\delta^{13} \mathrm{C}$ and $\delta^{15} \mathrm{~N}$ mucus to muscle, and (5) consumer as muscle values based on conversion using the linear models for $\delta^{13} \mathrm{C}$ and $\delta^{15} \mathrm{~N}$ scale to muscle.

and Percidae from 221 to $464 \mathrm{~mm}$. Grouping $S$. lucioperca into the two size classes of $<350 \mathrm{~mm}(194-340 \mathrm{~mm}, n=41)$ and $>351 \mathrm{~mm}(352-532 \mathrm{~mm}, n=41)$ revealed the percentage prey abundance was higher for invertebrates in the smaller size category $(<350 \mathrm{~mm}=15.8 \%)$ than in the larger size class $(>350 \mathrm{~mm}=0.5 \%)$. For Percidae, the opposite pattern was evident, with higher $\% P_{i}$ for Percidae in the larger size class $(>350 \mathrm{~mm}=20.3 \%)$ than in the smaller size class $(<350 \mathrm{~mm}=$ $3.7 \%)$. Percentage prey abundance remained similar for Cyprinidae in both size classes $(<350 \mathrm{~mm}=80.5 \%,>350 \mathrm{~mm}=$ 79.3\%; Tab. 4).

\section{Discussion}

The predictable relationships between the SI data of dorsal muscle and from fins, scales and epidermal mucus revealed that the tissues that can be collected by non-destructive methods can be used reliably within trophic studies on $S$. lucioperca, negating the collection of dorsal muscle samples. Mucus and fin showed no significant differences in isotope values compared to muscle, while scale was significantly depleted in $\delta^{15} \mathrm{~N}$ and enriched in $\delta^{13} \mathrm{C}$. Moreover, 

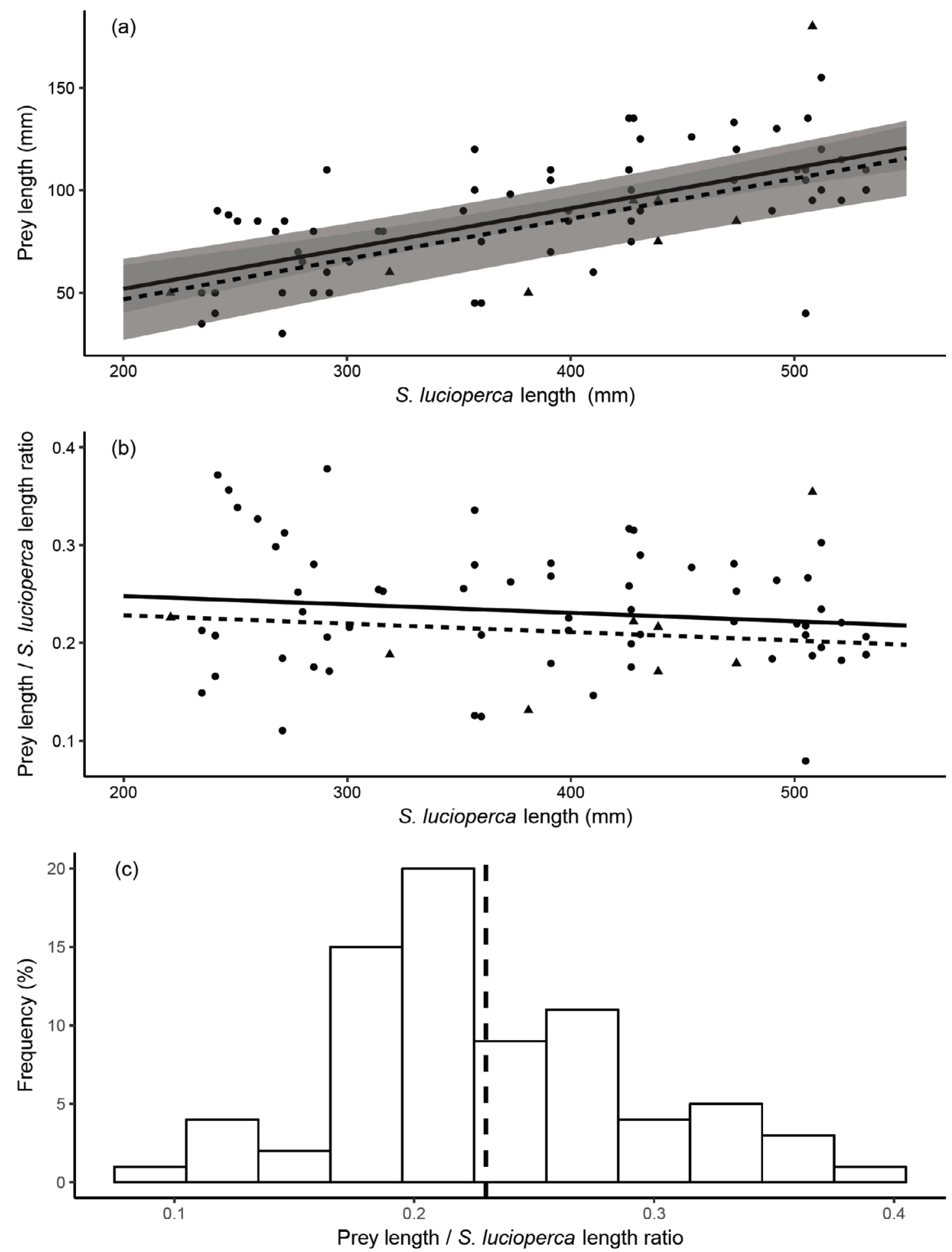

Fig. 5. S. lucioperca predator-prey relationships in the Grand Union Canal. (a) Predator size to prey size linear relationships (with $95 \%$ confidence intervals) for 'Cyprinidae' ( solid line) and 'Percidae' ( $\mathbf{A}$ dashed line). (b) Prey: predator length ratios versus $S$. lucioperca body length, where lines represent relationships according to linear regression for 'Cyprinidae' ( $\mathbf{O}$ solid line) and 'Percidae' ( $\mathbf{\Lambda}$ dashed line). (c) Relative frequency distributions of prey: predator length ratios, where the mean prey size to predator size ratio is shown at 0.22 .

the data provided here enables the application of the SI data from these tissues to Bayesian mixing models for predicting diet composition from putative prey SI data (Parnell et al., 2013; Phillips et al., 2014; Stock et al., 2018). In this study, the diet composition predictions from Bayesian mixing model results were broadly similar to those from stomach content analyses. The addition of stomach contents analysis, however, also provided data on the structured feeding relationships of 
Table 4. Frequency occurrence $\left(\% F_{i}\right)$ and prey-specific abundance $\left(\begin{array}{ll}\% & P_{i}\end{array}\right)$ of diet by prey types 'Cyprinidae', 'Percidae' and 'Invertebrate' for $S$. lucioperca from the Grand Union Canal.

\begin{tabular}{llll}
\hline Prey type & Size class & $\left(\% F_{i}\right)$ & $\left(\% P_{i}\right)$ \\
\hline Cyprinidae & $194-532 \mathrm{~mm}$ & 70.2 & 79.8 \\
& $194-340 \mathrm{~mm}$ & 73.2 & 80.5 \\
& $352-532 \mathrm{~mm}$ & 67.9 & 79.3 \\
Percidae & $194-532 \mathrm{~mm}$ & 21.3 & 13.1 \\
& $194-340 \mathrm{~mm}$ & 9.8 & 3.7 \\
& $352-532 \mathrm{~mm}$ & 30.2 & 20.3 \\
Invertebrates & $194-532 \mathrm{~mm}$ & 8.5 & 7.1 \\
& $194-340 \mathrm{~mm}$ & 17.1 & 15.8 \\
& $352-532 \mathrm{~mm}$ & 1.9 & 0.5 \\
\hline
\end{tabular}

these non-native piscivorous fish and their prey, revealing that these $S$. lucioperca were consuming small prey sizes relative to their body size. Finally, where diet assessments are being made in catch and release fisheries, the results suggest that tissue collection can successfully involve anglers, such as through scale collection (Kopp et al., 2009; Amat Trigo et al., 2017). In turn, this can help engage the public in research and build support for the conservation and management of aquatic resources (Cooke et al., 2013; Elmer et al., 2017; Arlinghaus et al., 2017).

The stomach contents analysis of this $S$. lucioperca population emphasised an inherent problem with the method; despite 180 fish being sampled, 98 had empty stomachs. Moreover, other studies that have utilised greater numbers of S. lucioperca have also reported this as an issue with, for example, over $20 \%$ of 376 sampled individuals having empty stomachs in a sample from an Iberian reservoir (Pérez-Bote and Roso, 2012), an average of $57.5 \%$ of S. lucioperca stomachs reported to be empty across seasons and years in a German lake (Schulze et al., 2012) and 42\% of 591 sampled S. lucioperca from Lake Peipsi in Estonia with empty stomachs (Kangur and Kangur, 1998). Additionally, high proportions of empty stomachs could be due to the sampling period, as data were collected during the spawning period (Lappalainen et al., 2003), which is known to be associated with reduced feeding in other piscivorous fishes (Dörner et al., 2003). Where this type of sampling regime is considered problematic, such as where it removes large numbers of fish from fisheries, where S. lucioperca (or other piscivorous sport fishes) is an important target species for C\&R (Hickley and Chare, 2004), stable isotope analysis clearly has high utility as a non-destructive dietary analysis tool.

Studies on the relationships of the SI values of fish dorsal muscle versus fin and scale tissues have shown that whilst differences in $\delta^{15} \mathrm{~N}$ are usually minor and often nonsignificant, there tends to be predictable shifts in $\delta^{13} \mathrm{C}$ between the tissues (e.g. Pinnegar and Polunin, 1999; Tronquart et al., 2012; Vašek et al., 2017). For example, in cyprinid fishes such as chub Squalius cephalus, barbel Barbus barbus and goldfish Carassius auratus, there was a predictable pattern of significant $\delta^{13} \mathrm{C}$ enrichment from muscle to fin to scales (Busst et al., 2015; Busst and Britton, 2016). This pattern of $\delta^{13} \mathrm{C}$ enrichment between these tissues was also apparent here for $S$. lucioperca, although only significant from scales to muscle, mucus and fin. For epidermal mucus, however, studies have only recently started to determine how its SI values compare with other tissues, with limited differences in $\delta^{15} \mathrm{~N}$ but with more variability in $\delta^{13} \mathrm{C}$ (e.g. Shigeta et al., 2017). Here, it was revealed that differences in $\delta^{13} \mathrm{C}$ between mucus and muscle were primarily in mucus being depleted, a contrast to fin and scales. In a study of catfish (Silurus asotus), there was also a general trend of depleted $\delta^{13} \mathrm{C}$ values of mucus relative to muscle (Maruyama et al., 2017), and depleted relative to both muscle and fin in three freshwater cyprinid species (Shigeta et al., 2017). The tissues used in this study are also known to have considerable differences in their stable isotope turnover rates, with mucus generally having shorter half-lives when compared with fin and scale tissues (Church et al., 2009; Maruyama et al., 2017; Shigeta et al., 2017). The complementary use of these tissues in SIA could therefore provide insights into diet over different timescales, although this was not able to be assessed here. The use of mucus in fish isotope studies is still relatively new compared to tissues such as muscle and fin (Church et al., 2009; Maruyama et al., 2015, 2017). As such, further development work is needed, both specifically for S. lucioperca and for fishes more generally, with increased focus required on the isotopic relationship of mucus with other tissues, their turnover rates and their fractionation factors with prey (Heady and Moore, 2013). This work should then enable the wider application of epidermal mucus to fish stable isotope studies, with this potentially highly advantageous due to its ability to be collected by non-invasive sampling techniques from live fish.

The results of both dietary assessment methods here revealed that this $S$. lucioperca population was functioning as an obligate piscivore, but only in its larger sizes. Some ontogenetic dietary shifts were evident, with smaller individuals having diets that included macroinvertebrates. Whilst S. lucioperca tend to switch to piscivory during the first year of life (Mittelbach and Persson, 1998), predictions from the Bayesian mixing models here suggested higher dietary contributions of invertebrates than fish for pikeperch $<350 \mathrm{~mm}$, where all fish were greater than 1 year old (E. Nolan, unpublished data). This pattern was also reflected in stomach content analyses. Obligate piscivory in $S$. lucioperca has been reported in a number of studies (e.g. Campbell, 1992; Kangur et al., 2007; Pérez-Bote and Roso, 2012), with the benefits of becoming piscivorous early in life being well documented (Mehner et al., 1996; van Densen et al., 1996; Mittelbach and Persson, 1998). However, in the absence of suitable-sized prey fish, $S$. lucioperca will continue to consume invertebrates species (Ginter et al., 2011), but are likely to grow slower than those that are completely piscivorous (Persson and Brönmark, 2008).

The stomach contents analysis of this $S$. lucioperca population also revealed that as $S$. lucioperca length increased, their prey fish size significantly increased, but that prey length to predator length ratios ranged between 0.08 and 0.38 . These ratios were similar to those of Keskinen and Marjomäki (2004), who also revealed that while lengths of $S$. lucioperca and their prey were positively correlated, their prey:predator size ratio was negatively correlated. Most prey were thus 
relatively small to the size of the predator, an outcome that cannot be explained by gape size limitations alone (Dörner et al., 2007). There was also no significant relationship between $S$. lucioperca length and $\delta^{15} \mathrm{~N}$ values, indicating that larger individuals were generally not feeding at higher trophic levels than smaller individuals (Post, 2002). Active prey choice is thought to be more important in explaining diet patterns in $S$. lucioperca than passive selection mechanisms (Turesson et al., 2002). This behavioural trait could explain the trends seen here, indicating that in the absence of suitablesized fish prey, S. lucioperca will utilise the resources available (i.e. invertebrates), but when fish prey are available, prey sizes are chosen, which give the highest energy return per time spent foraging. These results on prey sizes highlight the value that SCA data can provide SIA studies, albeit with the caveat that its use is destructive or, if using non-lethal stomach evacuation techniques, is invasive to the individual fish.

Pikeperch also usually occupy higher trophic positions than other piscivorous fishes, with this apparent from across a range of habitat typologies (Campbell, 1992; Kangur and Kangur, 1998; Keskinen and Marjomäki, 2004). This has been attributable to their piscivory of omnivorous cyprinid fishes (Keskinen and Marjomäki, 2004) and, in larger S. lucioperca, on other piscivores such as perch $P$. fluviatilis (Kopp et al., 2009). Other studies have also highlighted that cannibalism can be feature of $S$. lucioperca diet that tends to increase in importance with lengths over $250 \mathrm{~mm}$ (Campbell, 1992; Didenko and Gurbyk, 2016; Hempel et al., 2016), and so can help explain the high trophic position of larger individuals versus other piscivores (Kopp et al., 2009). The results here are generally consistent with these findings, with both $R$. rutilus and $P$. fluviatilis being the principal prey items encountered in stomachs. However, there was minimal evidence suggesting that these $S$. lucioperca were cannibalistic. This might be explained by the time of sampling, as young-of-the-year (YOY) S. lucioperca would not have been present in the population due to timing of spawning (Lappalainen et al., 2003). Both inter- and intra-cohort cannibalism in pikeperch has been shown to correlate with the density of juveniles in a population (Frankiewicz et al., 1999; Lappalainen et al., 2006). Indeed, cannibalism in S. lucioperca is seen as a key regulatory force in some populations (Mehner et al., 1996; Frankiewicz et al., 1999; Lappalainen et al., 2006). This again points to the limitations of the stomach content analyses in providing accurate dietary assessments, as it was only completed at a single time of year.

In summary, this study has provided relationships on the stable isotope data of a range of tissues from $S$. lucioperca. The application of these data to Bayesian mixing models predicted strong ontogenetic dietary patterns, with shifts from macroinvertebrates/fish to fish only as $S$. lucioperca length increased. These ontogenetic patterns were similarly evident in SCA, but with these data also highlight that as $S$. lucioperca length increased, their prey size significantly increased, although prey items remained relatively small. In entirety, these results suggest that when non-destructive sampling is required for sport fishes such as $S$. lucioperca, SIA can be used to provide robust dietary assessments. However, if SCA can be completed, then it can provide dietary data that are complementary to SIA and so help provide greater insights into their piscivory and predation pressure on native prey fishes.
Acknowledgements. We thank John Ellis of the Canal and Rivers Trust for access to the fish.

\section{References}

Amat Trigo F, Gutmann Roberts C, Britton JR. 2017. Spatial variability in the growth of invasive European barbel Barbus barbus in the River Severn basin, revealed using anglers as citizen scientists. Knowl Manag Aquat Ecosyst 418: 17.

Amundsen P-A, Gabler H-M, Staldvik FJ. 1996. A new approach to graphical analysis of feeding strategy from stomach contents data: modification of the Costello (1990) method. J Fish Biol 48: 607-614.

Argillier C, Barral M, Irz P. 2012. Growth and diet of the pikeperch Sander lucioperca (L.) in two French reservoirs. Arch Pol Fish 20: 191-200.

Arlinghaus R, Hallermann J. 2007. Effects of air exposure on mortality and growth of undersized pikeperch, Sander lucioperca, at low water temperatures with implications for catch-and-release fishing. Fish Manag Ecol 14: 155-160.

Arlinghaus R, Alós J, Beardmore B, Daedlow K, Dorow M, Fujitani M, Hühn D, Haider W, Hunt LM, Johnson BM, Johnston F, Klefoth T, Matsumura S, Monk C, Pagel T, Post JR, Rapp T, Riepe C, Ward H, Wolter C. 2017. Understanding and managing freshwater recreational fisheries as complex adaptive social-ecological systems. Rev Fish Sci Aquac 25: 1-41.

Arrington DA, Winemiller KO, Loftus WF, Akin S. 2002. How often do fishes "run on empty"? Ecology 83: 2145-2151.

Bašić T, Britton JR. 2015. Utility of fish scales from stock assessment surveys in stable isotope analysis for initial assessments of trophic relationships in riverine fish communities. J Appl Ichthyol 31: 296-300.

Bowen SH, Lutz EV, Ahlgren MO. 1995. Dietary protein and energy as determinants of food quality: trophic strategies compared. Ecology 76: 899-907.

Bower SD, Danylchuk AJ, Brownscombe JW, Thiem JD, Cooke SJ. 2016. Evaluating effects of catch-and-release angling on peacock bass (Cichla ocellaris) in a Puerto Rican reservoir: a rapid assessment approach. Fish Res 175: 95-102.

Brett MT, Goldman CR. 1996. A meta-analysis of the freshwater trophic cascade. Proc Natl Acad Sci USA 93: 7723-7726.

Britton JR, Busst GM. 2018. Stable isotope discrimination factors of omnivorous fishes: influence of tissue type, temperature, diet composition and formulated feeds. Hydrobiologia 808: 219-234.

Britton JR, Orsi ML. 2012. Non-native fish in aquaculture and sport fishing in Brazil: economic benefits versus risks to fish diversity in the upper River Paraná Basin. Rev Fish Biol Fish 22: 555-565.

Britton JR, Gozlan RE, Copp GH. 2011. Managing non-native fish in the environment. Fish Fish 12: 256-274.

Busst GMA, Britton JR. 2015. Quantifying the growth consequences for crucian carp Carassius carassius of competition from nonnative fishes. Ecol Freshw Fish 24: 489-492.

Busst GMA, Britton JR. 2016. High variability in stable isotope diettissue discrimination factors of two omnivorous freshwater fishes in controlled ex situ conditions. J Exp Biol 219: 1060-1068.

Busst GMA, Britton JR. 2017. Tissue-specific turnover rates of the nitrogen stable isotope as functions of time and growth in a cyprinid fish. Hydrobiologia 805: 1-12.

Busst GMA, Bašić T, Britton JR. 2015. Stable isotope signatures and trophic-step fractionation factors of fish tissues collected as non-lethal surrogates of dorsal muscle: non-lethal tissue surrogates for fish isotope studies. Rapid Commun Mass Spectrom 29: $1535-1544$. 
Campbell RNB. 1992. Food of an introduced population of pikeperch, Stizostedion lucioperca L., in lake Egirdir, Turkey. Aquac Res 23: 71-85.

Church MR, Ebersole JL, Rensmeyer KM, Couture RB, Barrows FT, Noakes DLG. 2009. Mucus: a new tissue fraction for rapid determination of fish diet switching using stable isotope analysis. Can J Fish Aquat Sci 66: 1-5.

Cooke SJ, Lapointe NWR, Martins EG, Thiem JD, Raby GD, Taylor MK, Beard Jr TD, Cowx IG. 2013. Failure to engage the public in issues related to inland fishes and fisheries: strategies for building public and political will to promote meaningful conservation. J Fish Biol 83: 997-1018.

Cook KV, Lennox RJ, Hinch SG, Cooke SJ. 2015. Fish out of water: how much air is too much? Fisheries 40: 452-461.

Copp GH, Wesley KJ, Kovac V, Ives MJ, Carter MG. 2003. Introduction and establishment of the pikeperch Stizostedion lucioperca (L.) in Stanborough Lake (Hertfordshire) and its dispersal in the Thames catchment. Lond Nat 82: 139-154.

Cortés E. 1997. A critical review of methods of studying fish feeding based on analysis of stomach contents: application to elasmobranch fishes. Can J Fish Aquat Sci 54: 726-738.

Costello MJ. 1990. Predator feeding strategy and prey importance: a new graphical analysis. J Fish Biol 36: 261-263.

Cucherousset J, Bouletreau S, Martino A, Roussel J-M, Santoul F. 2012. Using stable isotope analyses to determine the ecological effects of non-native fishes. Fish Manag Ecol 19: 111-119.

Densen WL van, Ligtvoet W, Roozen RW. 1996. Intra-cohort variation in the individual size of juvenile pikeperch, Stizostedion lucioperca, and perch, Perca fluviatilis, in relation to the size spectrum of their food items. Ann Zool Fenn 33: 495-506.

Didenko AV, Gurbyk AB. 2016. Spring diet and trophic relationships between piscivorous fishes in Kaniv Reservoir (Ukraine). Folia Zool 65: 15-26.

Dörner H, Berg S, Jacobsen L, Hülsmann S, Brojerg M, Wagner A. 2003. The feeding behaviour of large perch Perca fluviatilis (L.) in relation to food availability: a comparative study. Hydrobiologia 506: 427-434.

Dörner H, Hülsmann S, Hölker F, Skov C, Wagner A. 2007. Sizedependent predator-prey relationships between pikeperch and their prey fish. Ecol Freshw Fish 16: 307-314.

Drenner RW, Hambright RKD. 2002. Piscivores, trophic cascades, and lake management. Sci World J 2: 284-307.

Elmer LK, Kelly LA, Rivest S, Steell SC, Twardek WM, Danylchuk AJ, Arlinghaus R, Bennett JR, Cooke SJ. 2017. Angling into the future: ten commandments for recreational fisheries science, management, and stewardship in a good Anthropocene. Environ Manage 60: 165-175.

Elvira B, Almodóvar A. 2001. Freshwater fish introductions in Spain: facts and figures at the beginning of the 21st century. J Fish Biol 59: 323-331.

Frankiewicz P, Dabrowski K, Martyniak A, Zalewski M. 1999. Cannibalism as a regulatory force of pikeperch, Stizostedion lucioperca (L.), population dynamics in the lowland Sulejow reservoir (Central Poland). Hydrobiologia 408-409: 47-55.

Fry B. 2006. Stable Isotope Ecology. New York, NY: Springer.

Ginter K, Kangur K, Kangur A, Kangur P, Haldna M. 2011. Diet patterns and ontogenetic diet shift of pikeperch, Sander lucioperca (L.) fry in lakes Peipsi and Võrtsjärv (Estonia). Hydrobiologia 660: 79-91.

Gozlan RE. 2008. Introduction of non-native freshwater fish: is it all bad? Fish Fish 9: 106-115.

Gratwicke B, Marshall BE. 2001. The relationship between the exotic predators Micropterus salmoides and Serranochromis robustus and native stream fishes in Zimbabwe. J Fish Biol 58: $68-75$.

Hansson S, Arrhenius F, Nellbring S. 1997. Diet and growth of pikeperch (Stizostedion lucioperca L.) in a Baltic Sea area. Fish Res 31: 163-167.

Heady WN, Moore JW. 2013. Tissue turnover and stable isotope clocks to quantify resource shifts in anadromous rainbow trout. Oecologia 172: 21-34.

Hempel M, Neukamm R, Thiel R. 2016. Effects of introduced round goby (Neogobius melanostomus) on diet composition and growth of zander (Sander lucioperca), a main predator in European brackish waters. Aquat Invasions 11: 167-178.

Hickley P. 1986. Invasion by Zander and the Management of Fish Stocks. Philos Trans R Soc Lond B 314: 571-582.

Hickley P, Chare S. 2004. Fisheries for non-native species in England and Wales: angling or the environment? Fish Manag Ecol 11: 203-212.

Hutchinson JJ, Trueman CN. 2006. Stable isotope analyses of collagen in fish scales: limitations set by scale architecture. J Fish Biol 69: 1874-1880.

Jensen H, Kiljunen M, Amundsen P-A. 2012. Dietary ontogeny and niche shift to piscivory in lacustrine brown trout Salmo trutta revealed by stomach content and stable isotope analyses. $J$ Fish Biol 80: 2448-2462.

Kangur A, Kangur P. 1998. Diet composition and size-related changes in the feeding of pikeperch, Stizostedion lucioperca (Percidae) and pike, Esox lucius (Esocidae) in the Lake Peipsi (Estonia). Ital $J$ Zool 65: 255-259.

Kangur P, Kangur A, Kangur K. 2007. Dietary importance of various prey fishes for pikeperch Sander lucioperca (L.) in large shallow lake Võrtsjärv (Estonia). Proc Estonian Acad Sci Biol Ecol 56: 154-167

Keskinen T, Marjomäki TJ. 2004. Diet and prey size spectrum of pikeperch in lakes in central Finland. J Fish Biol 65: 1147-1153.

Kopp D, Cucherousset J, Syväranta J, Martino A, Céréghino R, Santoul F. 2009. Trophic ecology of the pikeperch (Sander lucioperca) in its introduced areas: a stable isotope approach in southwestern France. C R Biol 332: 741-746.

Lappalainen J, Dörner H, Wysujack K. 2003. Reproduction biology of pikeperch (Sander lucioperca (L.)): a review. Ecol Freshw Fish 12: 95-106.

Lappalainen J, Olin M, Vinni M. 2006. Pikeperch cannibalism: effects of abundance, size and condition. Ann Zool Fenn, 43: 35-44.

Linfield RSJ, Rickards RB. 1979. The zander in perspective. Aquac Res 10: 1-16.

Locke SA, Bulté G, Forbes MR, Marcogliese DJ. 2013. Estimating diet in individual pumpkinseed sunfish Lepomis gibbosus using stomach contents, stable isotopes and parasites. J Fish Biol 82: 522-537.

Maitland PS. 2004. Keys to the freshwater fish of Britain and Ireland, with notes on their distribution and ecology. https://doi.org/ 10.1111/j. 1365-2109. 2005.01267.x

Martínez del Rio C, Wolf N, Carleton SA, Gannes LZ. 2009. Isotopic ecology ten years after a call for more laboratory experiments. Biol Rev 84: 91-111.

Maruyama A, Shimonaka H, Ito T. 2015. Quick change in $\delta^{15} \mathrm{~N}$ values of fish mucus confirmed in the field using a migratory goby. Ecol Freshw Fish 24: 162-164.

Maruyama A, Tanahashi E, Hirayama T, Yonekura R. 2017. A comparison of changes in stable isotope ratios in the epidermal mucus and muscle tissue of slow-growing adult catfish. Ecol Freshw Fish 26: 636-642. 
Mehner T, Schultz H, Bauer D, Herbst R, Voigt H, Benndorf J. 1996. Intraguild predation and cannibalism in age-0 perch (Perca fluviatilis) and age-0 zander (Stizostedion lucioperca): interactions with zooplankton succession, prey fish availability and temperature. Ann Zool Fenn 33: 353-361.

Mittelbach GG, Persson L. 1998. The ontogeny of piscivory and its ecological consequences. Can J Fish Aquat Sci 55: 1454-1465.

Newsome SD, Rio CM del, Bearhop S, Phillips DL. 2007. A niche for isotopic ecology. Front Ecol Environ 5: 429-436.

Pace ML, Cole JJ, Carpenter SR, Kitchell JF. 1999. Trophic cascades revealed in diverse ecosystems. Trends Ecol Evol 14: 483-488.

Paradis Y, Bertolo A, Magnan P. 2008. What do the empty stomachs of northern pike (Esox lucius) reveal? Insights from carbon $\left(\delta^{13} \mathrm{C}\right)$ and nitrogen $\left(\delta^{15} \mathrm{~N}\right)$ stable isotopes. Environ Biol Fishes 83: 441-448.

Parnell AC, Phillips DL, Bearhop S, Semmens BX, Ward EJ, Moore JW, Jackson AL, Grey J, Kelly DJ, Inger R. 2013. Bayesian stable isotope mixing models. Environmetrics 24: 387-399.

Pelicice FM, Agostinho AA. 2009. Fish fauna destruction after the introduction of a non-native predator (Cichla kelberi) in a Neotropical reservoir. Biol Invasions 11: 1789-1801.

Pérez-Bote JL, Roso R. 2012. Growth and length-weight relationships of Sander lucioperca (Linnaeus, 1758) in the Alcántara Reservoir, south-western Spain: comparison with other water bodies in Eurasia. J Appl Ichthyol 28: 264-268.

Persson A, Brönmark C. 2002. Foraging capacity and resource synchronization in an ontogenetic diet switcher, pikeperch (Stizostedion lucioperca). Ecology 83: 3014-3022.

Persson A, Brönmark C. 2008. Pikeperch Sander lucioperca trapped between niches: foraging performance and prey selection in a piscivore on a planktivore diet. J Fish Biol 73: 793-808.

Phillips DL, Inger R, Bearhop S, Jackson AL, Moore JW, Parnell AC, Semmens BX, Ward EJ. 2014. Best practices for use of stable isotope mixing models in food-web studies. Can $J$ Zool 92: 823-835.

Pinnegar JK, Polunin NVC. 1999. Differential fractionation of $\delta^{13} \mathrm{C}$ and $\delta^{15} \mathrm{~N}$ among fish tissues: implications for the study of trophic interactions. Funct Ecol 13: 225-231.

Post DM. 2002. Using stable isotopes to estimate trophic position: models, methods, and assumptions. Ecology 83: 703-718.

Post DM, Layman CA, Arrington DA, Takimoto G, Quattrochi J, Montana CG. 2007. Getting to the fat of the matter: models, methods and assumptions for dealing with lipids in stable isotope analyses. Oecologia 152: 179-189.

R Core Team. 2018. R: a language and environment for statistical computing. R Foundation for Statistical Computing, Vienna, Austria. https://www.R-project.org/

Sandlund OT, Museth J, Øistad S. 2016. Migration, growth patterns, and diet of pike (Esox lucius) in a river reservoir and its inflowing river. Fish Res 173: 53-60.

Sato T, Watanabe K. 2014. Do stage-specific functional responses of consumers dampen the effects of subsidies on trophic cascades in streams? J Anim Ecol 83: 907-915.
Schulze T, Baade U, Dörner H, Eckmann R, Haertel-Borer SS, Hölker F, Mehner T. 2006. Response of the residential piscivorous fish community to introduction of a new predator type in a mesotrophic lake. Can J Fish Aquat Sci 63: 2202-2212.

Schulze T, Dörner H, Baade U, Hölker F. 2012. Dietary niche partitioning in a piscivorous fish guild in response to stocking of an additional competitor: the role of diet specialisation. Limnol Ecol Manag Inland Waters 42: 56-64.

Shigeta K, Tsuma S, Yonekura R, Kakamu H, Maruyama A. 2017. Isotopic analysis of epidermal mucus in freshwater fishes can reveal short-time diet variations. Ecol Res 32: 643-652.

Siepker MJ, Ostrand KG, Cooke SJ, Philipp DP, Wahl DH. 2007. A review of the effects of catch-and-release angling on black bass, Micropterus spp.: implications for conservation and management of populations. Fish Manag Ecol 14: 91-101.

Sinnatamby RN, Bowman JE, Dempson JB, Power M. 2007. An assessment of de-calcification procedures for $\delta^{13} \mathrm{C}$ and $\delta^{15} \mathrm{~N}$ analysis of yellow perch, walleye and Atlantic salmon scales. $J$ Fish Biol 70: 1630-1635.

Smith PA, Leah RT, Eaton JW. 1997 Removal as an option for management of an introduced piscivorous fish: the zander. In: Roberts J, Tilzey RDJ, eds. Controlling carp: exploring the options for Australia. Griffith, NSW: CSIRO Land and Water, pp. $74-86$.

Stock B, Semmens BX. 2016. MixSIAR GUI User Manual, Version 3.1. Stock BC, Jackson AL, Ward EJ, Parnell AC, Phillips DL, Semmens BX. 2018. Analyzing mixing systems using a new generation of Bayesian tracer mixing models. Peer J Prepr 6: e5096.

Tronquart NH, Mazeas L, Reuilly-Manenti L, Zahm A, Belliard J. 2012. Fish fins as non-lethal surrogates for muscle tissues in freshwater food web studies using stable isotopes. Rapid Commun Mass Spectrom 26: 1603-1608.

Turesson H, Persson A, Brönmark C. 2002. Prey size selection in piscivorous pikeperch (Stizostedion lucioperca) includes active prey choice. Ecol Freshw Fish 11: 223-233.

Vašek M, Vejř́k L, Vejříková I, Šmejkal M, Baran R, Muška M, Kubečka J, Peterka J. 2017. Development of non-lethal monitoring of stable isotopes in asp (Leuciscus aspius): a comparison of muscle, fin and scale tissues. Hydrobiologia 785: 327-335.

Ventura M, Jeppesen E. 2010. Evaluating the need for acid treatment prior to $\delta^{13} \mathrm{C}$ and $\delta^{15} \mathrm{~N}$ analysis of freshwater fish scales: effects of varying scale mineral content, lake productivity and $\mathrm{CO}_{2}$ concentration. Hydrobiologia 644: 245-259.

Wheeler A, Maitland PS. 1973. The scarcer freshwater fishes of the British Isles. J Fish Biol 5: 49-68.

Woodcock SH, Walther BD. 2014. Trace elements and stable isotopes in Atlantic tarpon scales reveal movements across estuarine gradients. Fish Res 153: 9-17.

Woodward G, Hildrew AG. 2002. Food web structure in riverine landscapes. Freshw Biol 47: 777-798.

Zhao T, Villéger S, Lek S, Cucherousset J. 2014. High intraspecific variability in the functional niche of a predator is associated with ontogenetic shift and individual specialization. Ecol Evol 4: $4649-4657$.

Cite this article as: Nolan ET, Britton JR. 2018. Diet of invasive pikeperch Sander lucioperca: developing non-destructive tissue sampling for stable isotope analysis with comparisons to stomach contents analysis. Knowl. Manag. Aquat. Ecosyst., 419, 49. 